\title{
THE EFFECT OF HYDROGEN ON THE HIGH TEMPERATURE MECHANICAL
}

PROPERTIES OF TN 718

\author{
W. Wei \\ University of Twente \\ Department of Mechanical Engineering \\ P.O. Box 217 \\ NL-7500 AE Enschede \\ The Netherlands
}

\begin{abstract}
A preliminary testing program was conducted to determine the effect of gaseous hydrogen on the tensile properties and fatigue life of IN 718 for long-term, high temperature applications. Tensile testing was conducted in hydrogen, helium or argon and air at temperatures up to $600^{\circ} \mathrm{C}$ and strain rates of $10^{-3}$ and $10^{-5} / \mathrm{s}$. Low cycle fatigue testing was conducted under similar conditions with a strain amplitude of $0.8 \%$ and $\mathrm{R}=0$. The results of testing in terms of yield and tensile strengths, ductility and cycles to failure were not completely conclusive. However, there is a tendency for lower tensile ductilities and shorter fatigue lives in hydrogen. Hydrogendislocation interactions and oxidation effects appear to play an important role in explaining this behavior.
\end{abstract}

\section{$\underline{\text { Introduction }}$}

The development of new generations of aero and industrial turbine engines includes concepts for the use of hydrogen fuel. This has raised a renewed interest in the effect of hydrogen on the long-term mechanical properties of materials. Most of the literature on hydrogen effects deals with the degradation of mechanical properties and embrittlement around room temperature or below. Materials selection for components such as hydrogen fuel tanks and fuel lines is thus covered. At higher temperatures, it is not as clear as to whether or not hydrogen can affect material properties. Because hydrogen mobility increases with increasing temperature, it could, for cxample, be assumed that the interaction of hydrogen with microstructural defects such as dislocations, grain boundaries and precipitates would be much weaker, and therefore that there should be a reduced or no effect of hydrogen on mechanical properties.

Work rclated to hydrogen use in rocket engines indicates, however, that hydrogen effects may indeed occur in combination with high temperatures [e.g. 1-3]. Many turbine engine materials, in particular, nickel based alloys, have an increasing solubility for hydrogen with increasing temperature. Upon rapid cooling, as is typical for the shutdown of a turbine engine, components exposed to hydrogen may become supersaturated, creating a possible embrittlement problem during the following engine start It has also been shown that hydrogen may effect the

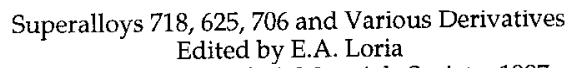


microstructure of nickel base alloys after long term exposure at high temperatures, leading to the degradation of high temperature properties [e.g. 4-5].

A preliminary investigation has therefore been conducted on the effect of hydrogen on the high temperature mechanical properties of a number of conventional aeroengine materials. This paper presents results on a typical disk alloy, IN 718. Tensile and low cycle fatigue testing was conducted under conditions simulating those expected in certain components of a hydrogen driven engine. The initial results indicate that care must be taken in component design and lifing for long term applications in hydrogen containing atmospheres at high temperatures.

\section{Experimental Procedures}

Tensile and low cycle fatigue testing were conducted on $\mathrm{IN} 718$ with the nominal composition of $19.0 \mathrm{Cr}-18.5 \mathrm{Fe}-3.0 \mathrm{Mo}-5.1 \mathrm{Nb}-0.5 \mathrm{Al}-0.9 \mathrm{Ti}-0.18 \mathrm{Si}-0.04 \mathrm{C}-0.002 \mathrm{~B}-$ rest Ni. Hourglass specimens were machined from plate material and from compressor disk material. The precise heat treatment conditions were not known. However, metallographic examination showed that the plate material had a typical solution annealed microstructure, Fig. 1, (denoted P in the tables) and the disk material had a solution annealed and aged condition microstructure consisting of fine grains with occasional clusters of coarser grains, Fig. 2. The microstructure of the specimens taken from the disk varied somewhat depending on the position in the disk. Specimens from two locations, denoted $\mathrm{A}$ and $\mathrm{B}$, were used in the present work, where the grain size of $\mathrm{B}$ was slightly larger than that of $\mathrm{A}$.

All testing was conducted in either 1 or 25 bar hydrogen, inert gas (argon or helium) and air. Tensile testing was conducted under position control with approximate strain rates of $10^{-3}$ and $10^{-5} / \mathrm{s}$. (At room temperature, $10^{-3} / \mathrm{s}$ is approximately the highest strain rate where hydrogen effects are generally measured.) Low cycle fatigue testing was conducted with a strain amplitude of $0.8 \%$ and and $\mathrm{R}=0$. The exact testing conditions can be found in Tables $1-3$ of the Results and Discussion section. Following testing, the fractured specimens were investigated using scanning electron microscopy (SEM).

\section{$\underline{\text { Results and Discussion }}$}

\section{Tensile Testing}

The results of the tensile testing in terms of $0.2 \%$ offset yield strength, ultimate tensile strength (UTS), and ductility are summarized in Tables 1-2. For each set of conditions, only one specimen was tested. (This also applies to the low cycle fatigue testing discussed below.) The results should therefore be interpreted with the appropriate degree of caution.

There appears to be little effect of hydrogen on the yield strength and UTS of the solution annealed plate material at $300^{\circ} \mathrm{C}$ for both strain rates, see Table 1 . However, in hydrogen, a slight decrease in the reduction of area can be seen. The results on the higher strength disk material at $300^{\circ} \mathrm{C}$ also show a lower ductility in hydrogen as well as a slightly lower UTS as compared to argon, Table 1. The specimen tested in air shows the highest strength but with similar ductility to the argon specimen.

Tensile testing of the disk material at $600^{\circ} \mathrm{C}$ and a strain rate of $10^{-5} / \mathrm{s}$ showed trends similar to 


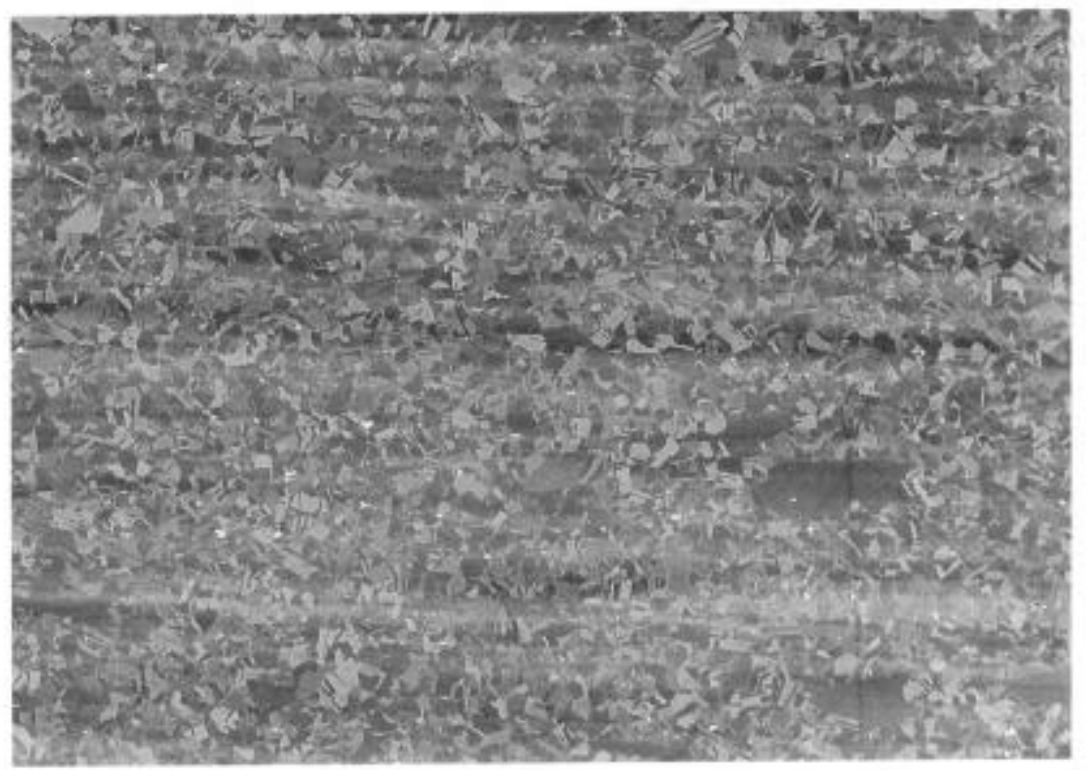

Fig. 1 - Typical microstructure of the IN 718 plate material perpendicular to the loading axis of the specimens (microstructure P).

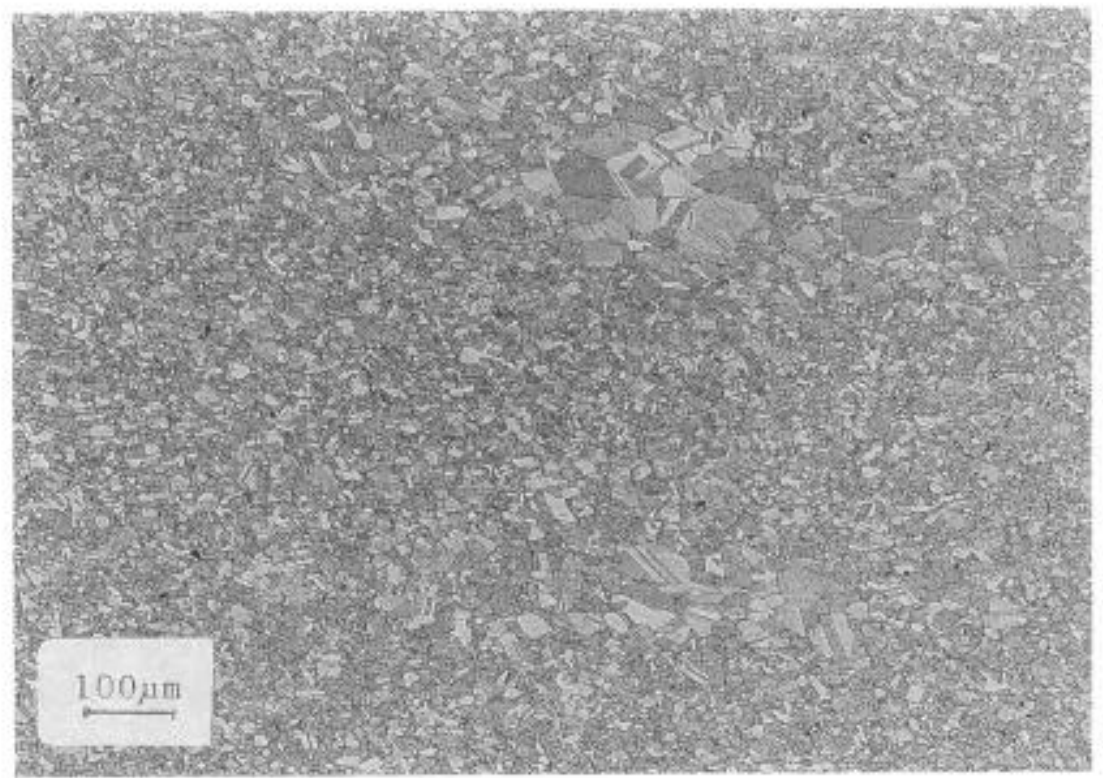

Fig. 2 - Typical microstructure of the IN 718 compressor disk material perpendicular to the loading axis (microstructure A). 
those found at $300^{\circ} \mathrm{C}$, compare Table 2 with Table 1 . At $600^{\circ} \mathrm{C}$ the UTS was slightly lower in hydrogen than in helium and in air, and there was also a decrease in ductility. Testing at a strain rate of $10^{-3} / \mathrm{s}$ produced results similar to the test conducted in helium at $10^{-5} / \mathrm{s}$. A further specimen was charged in hydrogen for 1 hour at $600^{\circ} \mathrm{C}$, air cooled and then immediately tested at room temperature (RT). While the UTS of that specimen agrees with the literature $[1,3,8]$ for uncharged material, there is a significant reduction in the ductility due to charging.

Scanning electron microscopy of all tensile specimens showed what appeared to be typical ductile fracture surfaces with microvoid coalescence, e.g. Figs. 3ab or 4ab. However, closer examination revealed fine differences which could explain at least the consistent differences in ducti-

Table 1

Results of tensile testing at $300^{\circ} \mathrm{C}$

\begin{tabular}{lcccccc}
$\begin{array}{l}\text { Atmosphere } \\
\quad \text { (bar) }\end{array}$ & $\begin{array}{c}\text { Strain rate } \\
(1 / \mathrm{s})\end{array}$ & $\begin{array}{c}\sigma_{0.2} \\
(\mathrm{MPa})\end{array}$ & $\begin{array}{c}\text { UTS } \\
(\mathrm{MPa})\end{array}$ & $\begin{array}{c}\mathrm{R} . \mathrm{A} \\
(\%)\end{array}$ & $\begin{array}{c}\text { Flongation } \\
(\%)\end{array}$ & $\begin{array}{c}\text { Micro- } \\
\text { structure }\end{array}$ \\
$\begin{array}{l}\text { Hydrogen (25) } \\
\text { Argon (25) }\end{array}$ & $10^{-5}$ & 301 & 743 & 50 & 90 & $\mathrm{P}$ \\
& $10^{-5}$ & 314 & 752 & 59 & 87 & $\mathrm{P}$ \\
$\begin{array}{l}\text { Hydrogen (25) } \\
\text { Argon (25) }\end{array}$ & $10^{-3}$ & 305 & 734 & 14 & 87 & $\mathrm{P}$ \\
& $10^{-3}$ & 287 & 725 & 51 & 90 & $\mathrm{P}$ \\
Hydrogen (25) & $10^{-5}$ & 1220 & 1265 & 9.2 & 21.3 & $\mathrm{~A}$ \\
Argon (25) & $10^{-5}$ & 1150 & 1322 & 13.3 & 29.6 & $\mathrm{~A}$ \\
Luff (1) & $10^{-5}$ & $\approx 1182$ & 1383 & 13.8 & 28.3 & $\mathrm{~A}$ \\
\hline
\end{tabular}

Table 2

Results of tensile testing at $600^{\circ} \mathrm{C}$

\begin{tabular}{|c|c|c|c|c|c|c|}
\hline $\begin{array}{l}\text { Atmosphere } \\
\text { (bar) }\end{array}$ & $\begin{array}{c}\text { Strain rate } \\
(1 / \mathrm{s})\end{array}$ & $\begin{array}{c}\sigma_{0.2} \\
(\mathrm{MPa})\end{array}$ & $\begin{array}{l}\text { UTS } \\
(\mathrm{MPa})\end{array}$ & $\begin{array}{l}\text { R.A. } \\
(\%)\end{array}$ & $\begin{array}{c}\text { Elongation } \\
(\%)\end{array}$ & $\begin{array}{l}\text { Micro- } \\
\text { structure }\end{array}$ \\
\hline Hydrogen (1) & $10^{-5}$ & 1090 & 1140 & n.a. & n.a. & B \\
\hline $\begin{array}{l}\text { Charged } 1 \mathrm{~h} \\
\text { in hydrogen } \\
\text { (1) at } 600^{\circ} \mathrm{C} \text {, } \\
\text { tested at } \mathrm{RT}\end{array}$ & $\begin{array}{l}10^{-5} \\
10^{-5}\end{array}$ & $\begin{array}{l}1146 \\
1366\end{array}$ & $\begin{array}{l}1194 \\
1572\end{array}$ & $\begin{array}{c}36.0 \\
5.1\end{array}$ & $\begin{array}{c}15.0 \\
6.5\end{array}$ & $\begin{array}{l}\mathrm{B} \\
\mathrm{B}\end{array}$ \\
\hline $\begin{array}{l}\text { Helium (1) } \\
\text { Air (1) }\end{array}$ & $\begin{array}{l}10^{-5} \\
10^{-5}\end{array}$ & $\begin{array}{r}1061 \\
\approx 1115\end{array}$ & $\begin{array}{l}1246 \\
1162\end{array}$ & $\begin{array}{l}57.0 \\
58.0\end{array}$ & $\begin{array}{l}20.0 \\
21.8\end{array}$ & $\begin{array}{l}\mathrm{B} \\
\mathrm{B}\end{array}$ \\
\hline Hydrogen (1) & $10^{-3}$ & 1067 & 1274 & 57.0 & 20.0 & A \\
\hline
\end{tabular}

n.a. - not available 
lity between the specimens tested in hydrogen and those tested in the other atmospheres. Overviews of a disk material specimen tested in hydrogen and one tested in argon at $300^{\circ} \mathrm{C}$ at a strain rate of $10^{-5} / \mathrm{s}$ are shown in Figs. $3 \mathrm{a}$ and $4 \mathrm{a}$ respectively. It can be seen, that while both show typical features of ductile failure, a higher percentage of flat fracture can be seen in the center of the specimen tested in hydrogen. Under other conditions, the hydrogen specimens showed several sharply angled facets in the center region, whereas the argon specimens showed almost completely flat shear failure $45^{\circ}$ to the loading axis. At higher magnification, it can be seen that the microvoid structure is somewhat coarser for the specimen tested in argon than that tested in hydrogen, compare Figs. $4 \mathrm{~b}$ and $3 \mathrm{~b}$ (specimens tested at $600^{\circ} \mathrm{C}$ ). The fracture characteristics of the air specimens tended to lie somewhere between these two atmospheres. For the specimens tested at $10^{-3} / \mathrm{s}$ as well as for the lower strength plate material, some differences were also observed but were less obvious. It should be noted that hydrogen embrittlement was most evident for the specimen charged at $600^{\circ} \mathrm{C}$ and tested at RT, where mixed cleavage and microvoid coalescence was observed on the fracture surface.

Examination of the slip band structure on the flanks of the specimens just below the fracture surface also revealed subtle differences. A somewhat irregular slip band cell structure was found for the disk material tested in hydrogen at $300^{\circ} \mathrm{C}$. The structure consisted predominantly of small cells with a dimension of roughly $15 \times 15 \mu \mathrm{m}$, Fig. 3c. Secondary cracking was zigzag in form and followed the small cell structure. For disk material tested in argon at $300^{\circ} \mathrm{C}$, there appeared to be a more clearly defined slip band structure with major cells ca. $100 \times 100 \mu \mathrm{m}$ containing a number of $25 \times 25 \mu \mathrm{m}$ subcells, Fig. $4 \mathrm{c}$. Some secondary cracking was observed consisting of long, straight cracks which followed the length of 1 or 2 major cells. Again, the air specimens showed features somewhere between the other two test atmospheres, and similar but less obvious differences were observed for the specimens tested at $10^{-3} / \mathrm{s}$ and for the lower strength plate material.

The results of high temperature tensile testing therefore seem to indicate that the main effect of hydrogen is to reduce ductility by effecting the slip process. In particular, this is shown by the differences in slip band structure, where the specimens tested in hydrogen show a finer, more irregular structure than in argon or air. In addition, there is a finer microvoid structure in hydrogen. This interpretation agrees with the conclusions of Hicks and Altstetter [7-8] who found that for IN 718 at RT, internal hydrogen localizes dislocation motion to particular slip bands (enhanced localized plasticity mechanism). This results in, among other features, a finer microvoid structure on the fracture surface. It has also been reported that hydrogen induces microvoid initiation and finer microvoid structures in certain $\mathrm{Al}$ alloys [9].

\section{Low Cycle Fatigue Testing}

The results of the low cycle fatigue testing of the plate and disk materials are summarized in Tables 3 and 4 respectively. The results of testing of the plate material, Table 3 , are not conclusive, showing a slightly lower fatigue life in hydrogen at $500^{\circ} \mathrm{C}$, but a longer life at $600^{\circ} \mathrm{C}$. The cffect of an oxidizing atmosphere, air, is also unclear. For the disk material, similar scatter in the data was found. The scatter in this case may be related in part to the different microstructures of the specimens.

Initial SEM cxamination of the fatigue crack surfaces of specimens showed transgranular cracking with no significant effect of the various test conditions which could account for the differences in fatigue lives. Some oxidation was, however, found on the specimens tested in hydrogen and helium, which may have contributed to the scatter in fatigue lives. Work on the low 


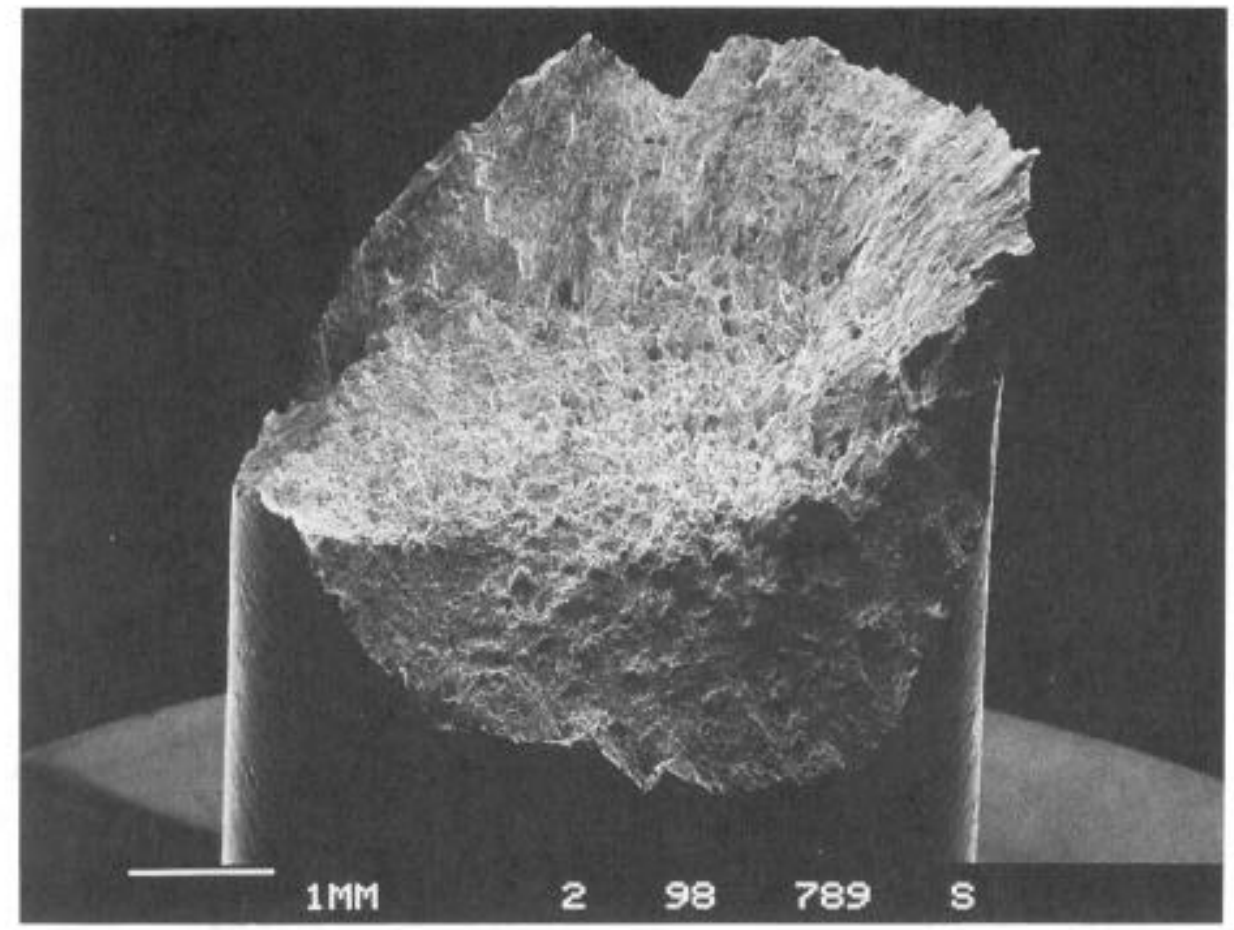

Fig. 3a - Overview of fracture surface of disk material tensile tested at $300^{\circ} \mathrm{C}$ in hydrogen.

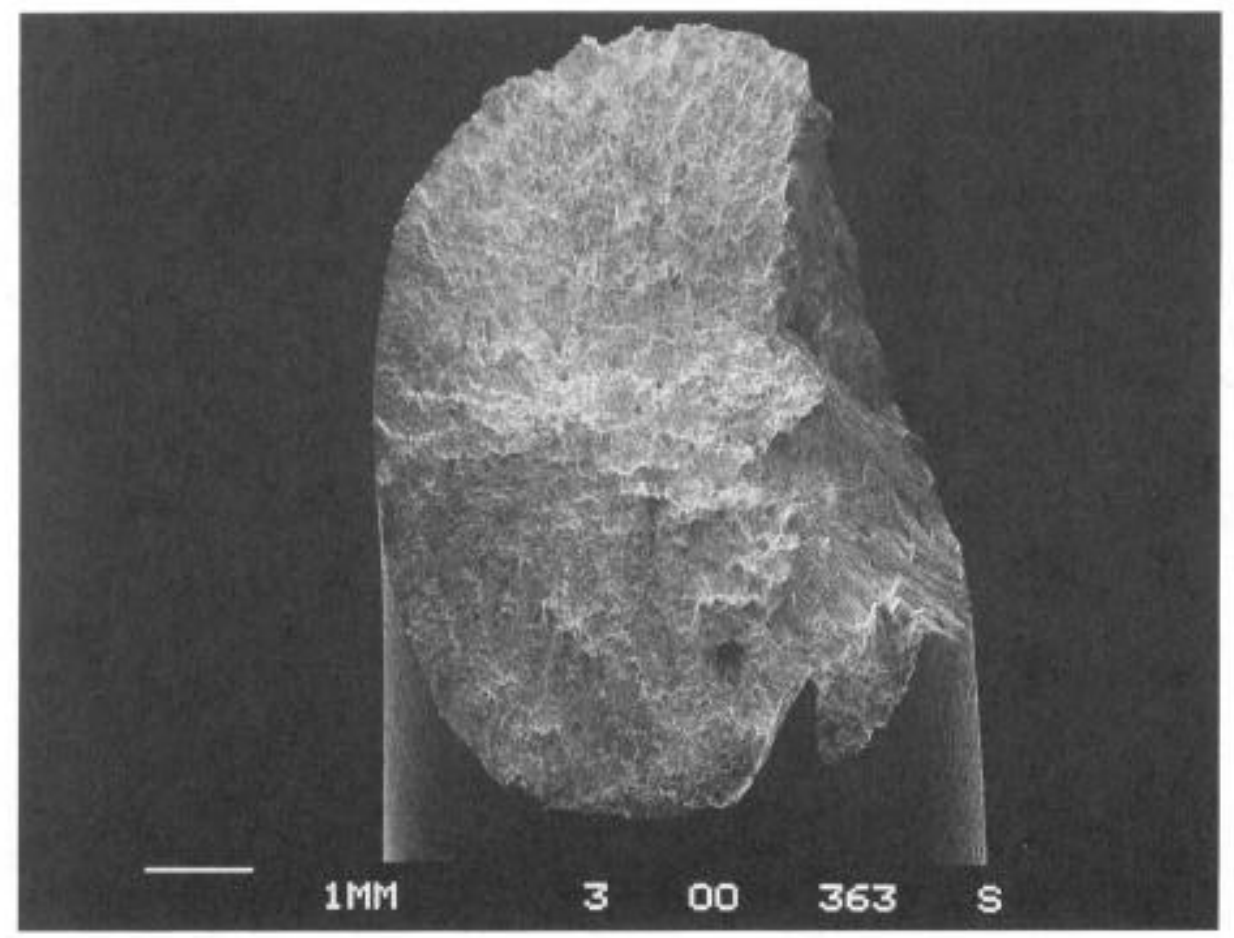

Fig. 4a - Overview of fracture surface of disk material tensile tested at $300^{\circ} \mathrm{C}$ in argon. 


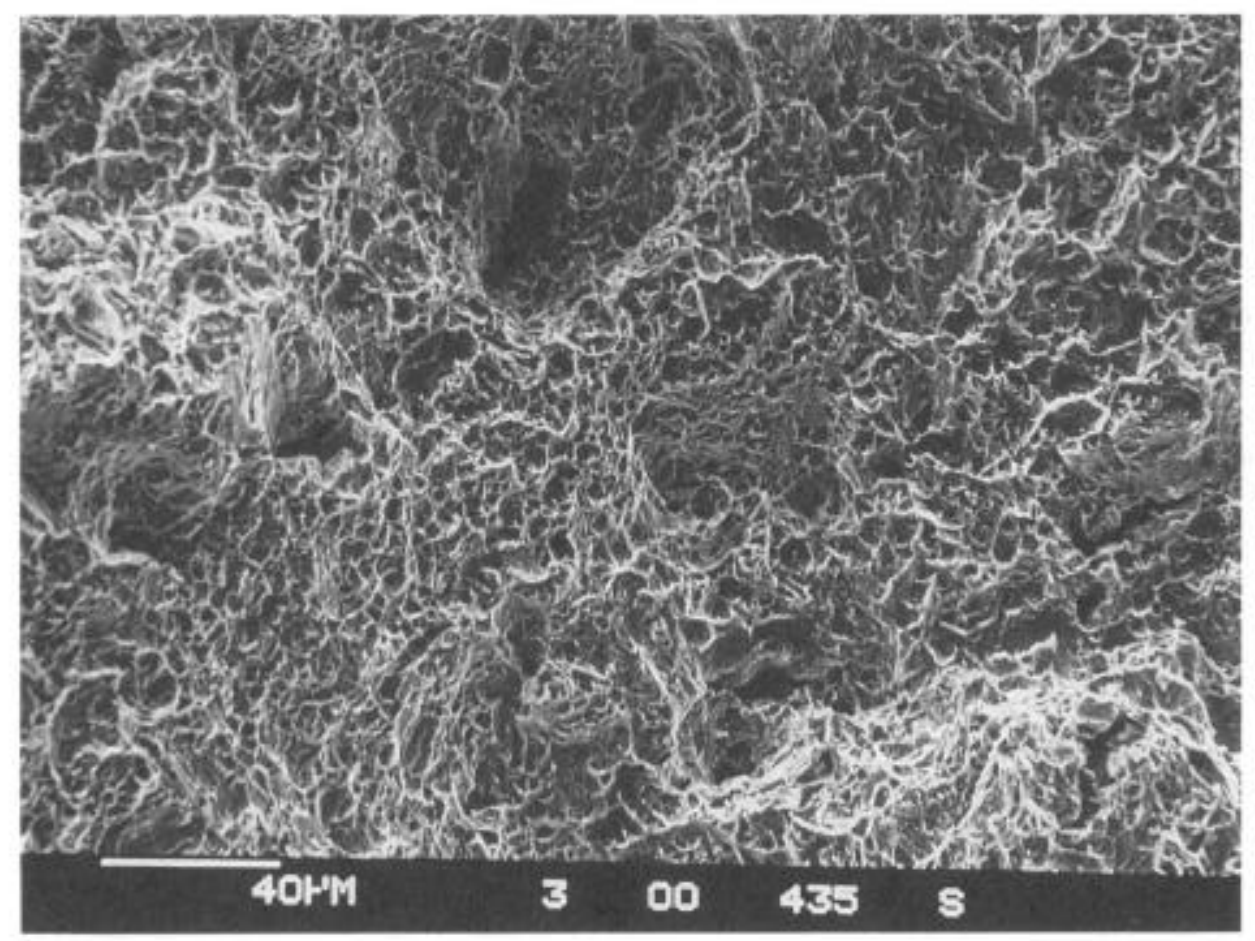

Fig. $3 \mathrm{~b}$ - Microvoid structure of disk material tensile tested at $600^{\circ} \mathrm{C}$ in hydrogen.

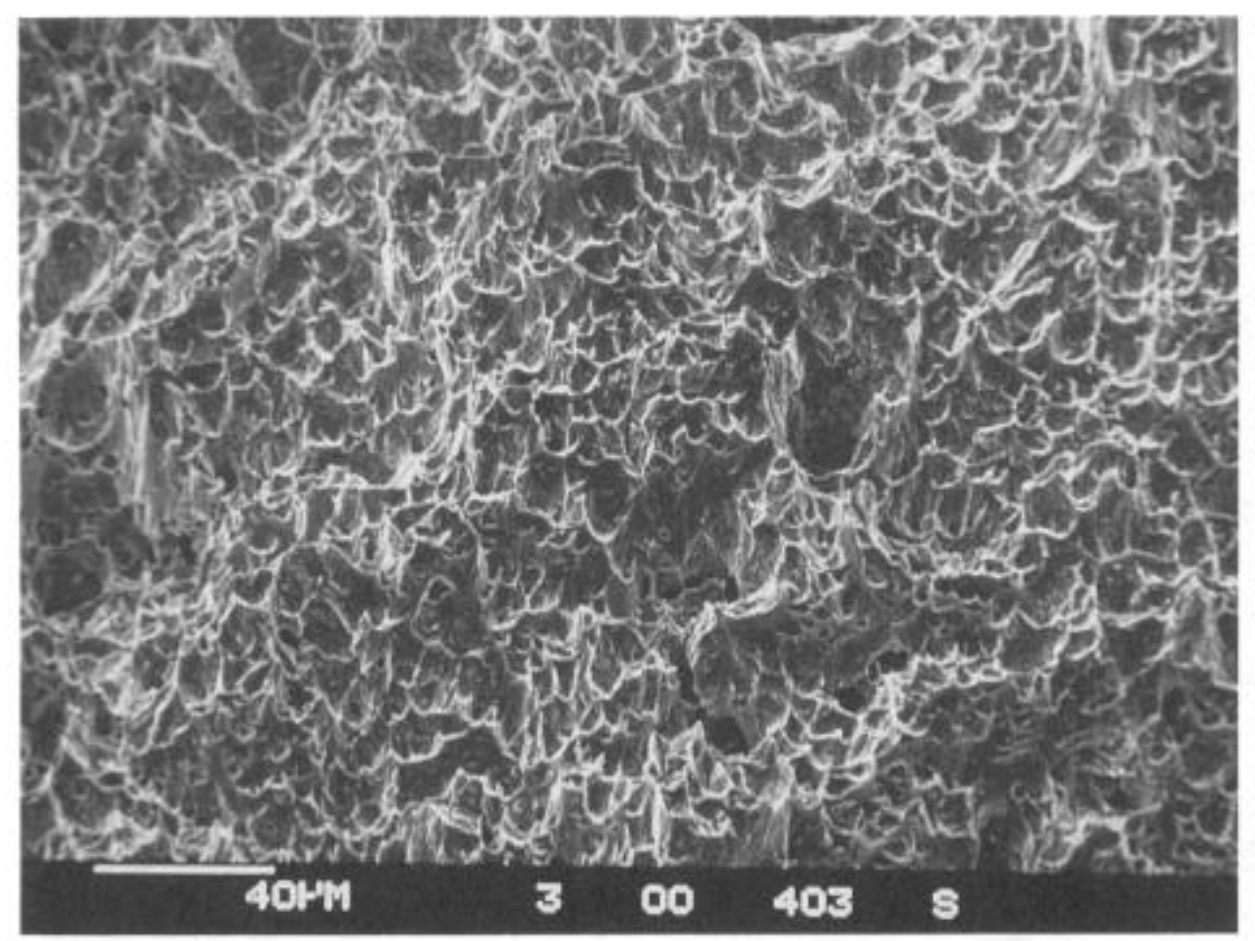

Fig. $4 \mathrm{~b}$ - Microvoid structure of disk material tensile tested at $600^{\circ} \mathrm{C}$ in helium. 


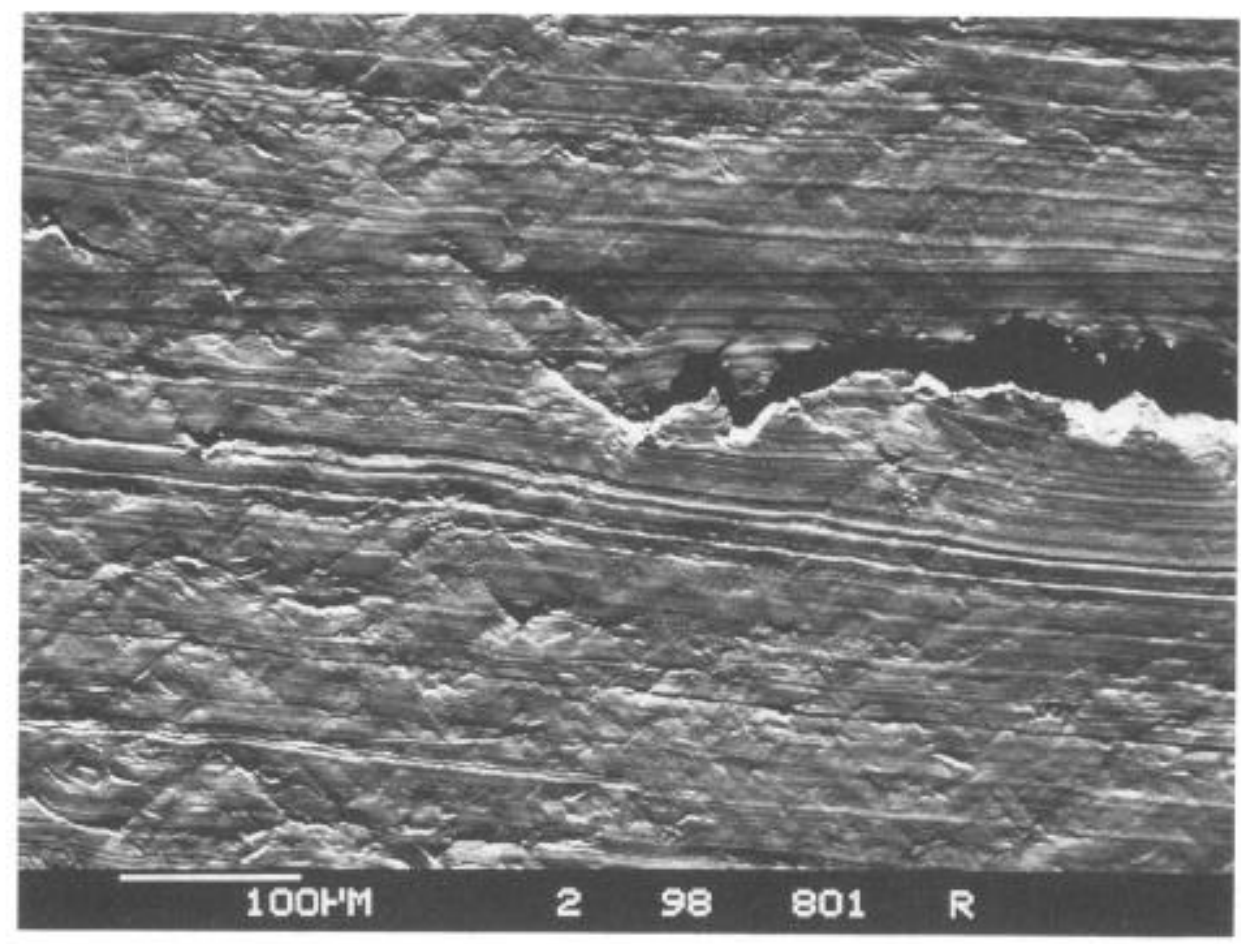

Fig $3 \mathrm{c}$ - Slip band structure of disk material tensile tested at $300^{\circ} \mathrm{C}$ in hydrogen (The relatively straight horizontal lines are machining marks.)

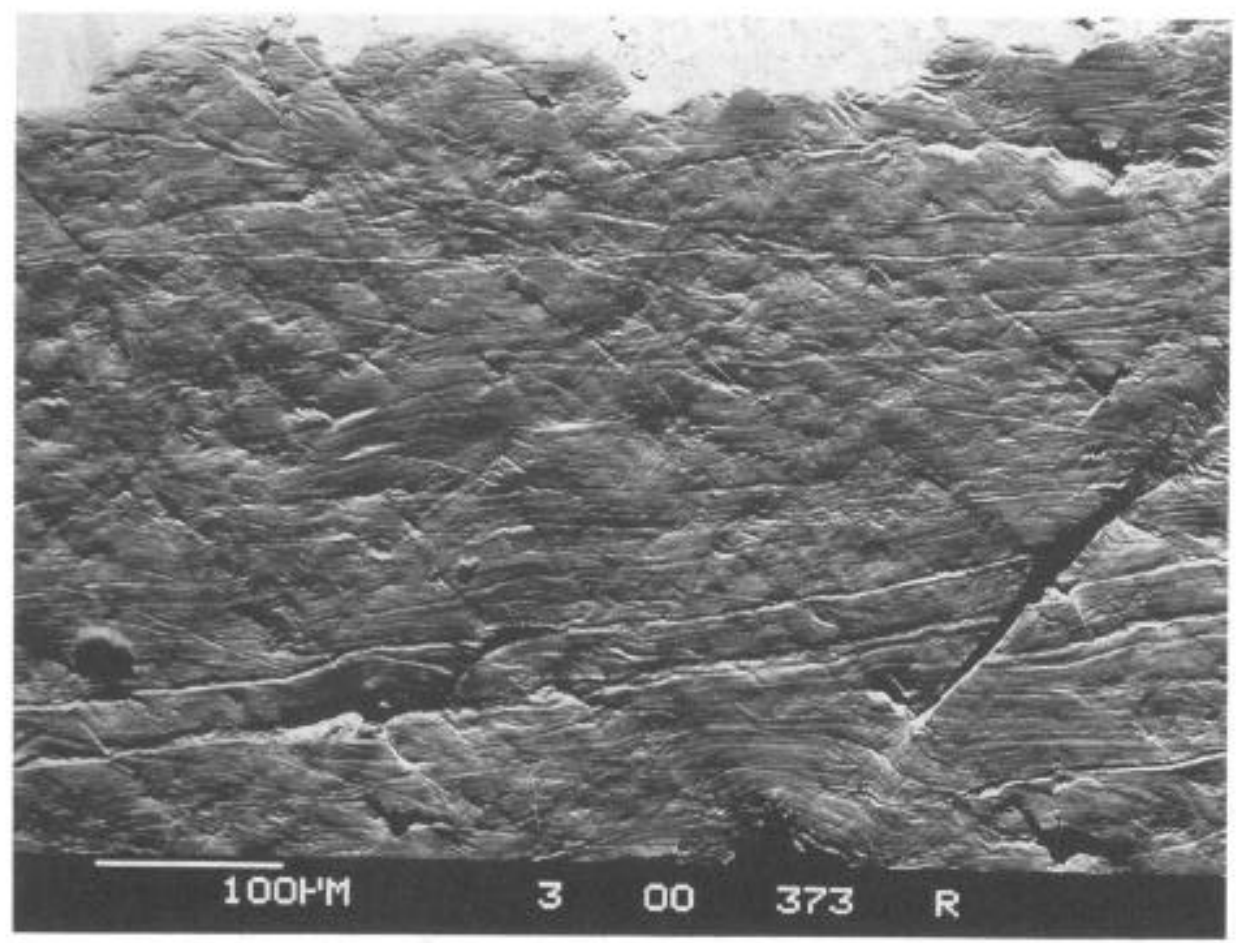

Fig. $4 \mathrm{c}$ - Slip band structure of disk material tensile tested at $300^{\circ} \mathrm{C}$ in argon. 
cycle fatigue of IN 100 at $600^{\circ} \mathrm{C}$ has shown that crack propagation rates in both hydrogen and inert gas or vacuum are slightly accelerated as compared to air [10]. In those more carefully controlled atmospheres, little or no oxidation was found on the surfaces of the specimens tested in hydrogen or inert gas. It was suggested that hydrogen may not be completely or directly responsible for a possible degradation in long term properties. In fact, high temperature oxidation in air was thought to have a crack tip blunting effect, leading to apparently lower in crack growth rates. For the present case, this means that the presence of residual oxidation in the hydrogen and helium testing atmospheres may also have lead to retardation of crack growth in certain cases and thus to the inconsistencies in the fatigue lives. This effect is being currently investigated in continuing SEM studies.

\section{Conclusions}

A preliminary testing program was conducted to determine the effect of gaseous hydrogen on the tensile properties and fatigue life of $\mathrm{IN} 718$ for high temperature applications. It has been shown that the ductility of solution treated and aged compressor disk material is reduced in hydrogen at $300^{\circ}$ and $600^{\circ} \mathrm{C}$, and to a lesser extent for solution annealed plate material. The results of low cycle fatigue in terms of cycles to failure are inconclusive but indicate that there may be an environmental effect. The effect of hydrogen on the tensile and low cycle fatigue behavior of IN 718 may be either through a direct enhanced plasticity mechanism, or indirectly due to the absence of oxide retardation of crack growth, or both. In any case, the results show that care must therefore be taken in the selection and interpretation of hydrogen tests for use in predicting the behavior of $1 \mathrm{~N} 718$ or other alloys in general under long term, static and (thermal) cyclic loading conditions expected in future hydrogen powered engines.

\section{Acknowledgements}

This program was conducted by the author while at the MTU Motoren-und-Turbinen-Union $\mathrm{GmbH}$, Munich, Germany and was financed by the German Research Ministry and MTU. Thanks go to Dr. M. Kornmann of Battelle, Geneva, Switzerland, and Mr. R. Deska and Mr. Lampl from MAN Neue Technologie GmbH, Munich for performing much of the mechanical testing, and to Dr. H. Klingele, Institut Dr. Klingele, Munich for the SEM work.

\section{$\underline{\text { References }}$}

1. L.G. Fritzemeier and W.T. Chandler, "Hydrogen Embrittlement - Rocket Engine Applications", in Superalloys, Supercomposites and Superceramics (Boston: Academic Press, Inc., 1989), 491-524.

2. C.P. DeLuca and B.A. Cowles, "Fatigue and Fracture of Single Crystal Nickel in High Pressure Hydrogen", in Hydrogen Effects on Material Behavior, N.R. Moody and A.W. Thompson, eds. (Warrendale, PA: The Metallurgical Society of AIME, 1990), 603-612.

3. R.P. Jewett and J.A. Halchak, "The Use of Alloy 718 in the Space Shuttle Main Engine", in Superalloys 718, 625 and Various Derivatives, E.A. Loria, ed. (Warrendale, PA: The Metallurgical Society of AIME, 1991), 749-760.

4. M. Hasegawa and M. Osawa, "Hydrogen Damage of Nickel-base Heat Resistant Alloys", Transactions of the Japanese Iron and Steel Institute 21 (1) (1981) 25-31.

5. M. Gao, J.B. Boodey, R.P. Wei and W. Wei, "Hydrogen Solubility and Microstructure of Hastelloy X", Scripta Metallurgica et Materialia 26 (1992) 63-68.

6. Company literature, INCO Alloys International. 
7. P.D. Hicks and C.J. Altstetter, "Internal Hydrogen Effects on Tensile Properties of Iron- and Nickel-Base Superalloys", Metallurgical Transactions A 21A (1990) 365-372.

8. P.D. Hicks and C.J. Altstetter, "Comparison of Internal Hydrogen Embrittlement of Superalloys 718 and 625", in Superalloys 718, 625 and Various Derivatives, E.A. Loria, editor (Warrendale, PA: The Metallurgical Society of AIME, 1991) 635-651.

9. R.E. Swanson, "Hydrogen Effects on Ductile Fracture", in Environmental Degradation of Engineering Materials III, (University Park: Pennsylvania State University, 1987), 133-148.

10.W. Wei, N.S. Stoloff, M. Pinkert and P. Korinko, "The Effect of Hydrogen on the High Temperature Fatigue of IN 100", in preparation.

Table 3

Results of low cycle fatigue testing of plate material

\begin{tabular}{|c|c|c|c|}
\hline $\begin{array}{l}\text { Atmosphere } \\
\text { (1 bar) }\end{array}$ & $\begin{array}{c}\text { Temperature } \\
\left({ }^{\circ} \mathrm{C}\right)\end{array}$ & $\begin{array}{c}\Delta \varepsilon \\
(\% ; \mathrm{R}=0.1)\end{array}$ & $\begin{array}{l}\text { Cycles to } \\
\text { Failure }\end{array}$ \\
\hline Hydrogen & 500 & 0.8 & 6023 \\
\hline Helium & 500 & 0.8 & 9124 \\
\hline Air & 500 & 0.8 & $>1378$ \\
\hline Hydrogen & 600 & 0.8 & 8454 \\
\hline Helium & 600 & 0.8 & 6835 \\
\hline Air & 600 & 0.8 & 7337 \\
\hline
\end{tabular}

Table 4

Results of low cycle fatigue testing of disk material

\begin{tabular}{|c|c|c|c|c|}
\hline $\begin{array}{l}\text { Atmosphere } \\
\text { (1 bar) }\end{array}$ & $\begin{array}{c}\text { Temperature } \\
\left({ }^{\circ} \mathrm{C}\right)\end{array}$ & $\begin{array}{c}\text { Strain } \\
\text { Amplitude } \\
(\mathrm{R}=0.1)\end{array}$ & $\begin{array}{l}\text { Cycles to } \\
\text { Failure }\end{array}$ & $\begin{array}{c}\text { Micro- } \\
\text { structure }\end{array}$ \\
\hline Hydrogen & 500 & 0.8 & 12502 & $\mathrm{~A}$ \\
\hline Helium & 500 & 0.8 & 6554 & A \\
\hline Hydrogen & 500 & 0.8 & 10695 & B \\
\hline Helium & 500 & 0.8 & $>15000$ & B \\
\hline Hydrogen & 600 & 0.8 & 6738 & $\mathrm{~B}$ \\
\hline Helium & 600 & 0.8 & 3945 & B \\
\hline
\end{tabular}

